\title{
Research on the Open Learning Model of Construction Organization Based on Online Open Course
}

\author{
Qianfen Cai \\ School of Civil Engineering and Architecture \\ Wuhan University of Technology \\ 430070, Wuhan, China
}

\begin{abstract}
In order to innovate traditional teaching methods of construction organization, this work researched on the expansion of teaching and learning methods in this course. Through the establishment of a new effective learning method that meets the requirements of educational reform and quality education, students' enthusiasm, initiative and creativity in the learning process can be fully utilized. The open learning model enables students to truly become the main body of information processing and the active constructor of curriculum knowledge. In addition, teachers can also improve their teaching ability in the open teaching model.
\end{abstract}

Keywords-Open learning; Online open courses; Construction organization; Learning model

\section{INTRODUCTION}

The development of hybrid teaching based on online open courses provides not only more abundant learning resources for college students' learning activities but also more ways and means to obtain knowledge information. The open learning model is a new learning method that meets the requirements of the times and is an effective way to improve learning efficiency. Open learning platform [1] is built and run based on Web and uses LAMP (Linux, Apache, MySQL, PHP) as a technical framework, through which teachers and students can communicate. The development of modern science and technology, especially the development of information technology, puts new demands on the open learning model and opens up new avenues for open learning. Based on the systematic elaboration of the open learning model, this work intended to explore related issues of the open learning model in the construction organization course under the background of mixed teaching.

\section{CHARACTERISTICS OF CONSTRUCTION ORGANIZATION COURSE CONTENT}

\section{A. Content has strong practicality}

According to the Code for Construction Organization Plan of Building Engineering [2] (GB/T50502-2009), the construction organization plan is a comprehensive document that is prepared for the construction project and is used to guide technology, economy and organization of the construction. It is a comprehensive technical and economic document that is compiled before construction and is used to guide the whole process of the proposed project from bidding, signing of construction contract and construction preparation to completion acceptance, which is a powerful means for scientific organization of the entire construction activity. The content of the course is closely related to the actual production, and it is practical. Therefore, mastering the content of this course needs to associate closely with the actual work.

\section{B. The course content has large amounts of information and it does not achieve an ideal training effect}

The basic task of the construction organization plan [3] is to select economic, reasonable and effective construction plan according to the owner's requirements for construction projects It also determines a compact and balanced construction schedule, formulates effective technical organization measures, optimizes configuration and saves production factors (resources) such as labor, material, machinery equipment, capital and technology, therefore it can use space on the construction site reasonably. Based on this, the construction can be carried out in an orderly manner, achieving the goal of better and more economical. The experimental teaching time and training place of the course are relatively insufficient, which affects the cultivation and training of students' practical ability. In addition, the main content of practice teaching in many colleges and universities still stays in the curriculum design of the construction organization, but rarely considers the construction preparation, the discussion of the construction plan and the optimization of the unit project construction schedule. The teaching content and training content are out of touch with the real business, as a result, the knowledge of construction organization that students master is one-sided and fragmented. It is difficult to establish the professional awareness and professional quality of standard construction project organization through teaching and training, not to mention the cultivation of innovative spirit, which does not meet the needs of the society for organization talents in the construction industry.

\section{Students are not motivated enough}

The motivation for students to learn construction organization lies in their enthusiasm for learning. The improvement of learning enthusiasm is formed through the joint action of teaching and practice. Renewing teaching concepts is fundamental to motivate students to learn actively. The innovation and reform of the teaching process is the main way to encourage students to learn positively. Students' lack of 
understanding of the majors they have learned has led to low enthusiasm of many students. Students only accept the professional knowledge of construction organization on the surface, but they cannot think actively, thus failing to achieve the purpose of applying what they have learned to practice. There is a vicious circle between teaching and learning, so it is difficult to develop teaching smoothly, which in turn affects the enthusiasm and initiative of students. Therefore, only by continuously strengthening innovation in the model of teaching and learning can the passive situation be changed fundamentally.

\section{It is necessary to build up the practical ability of the teaching staff}

Teachers are the leaders of teaching, and they undertake important educational responsibilities. It is necessary to continuously develop teaching resources, improve team building, integrate teaching resources and maximize the use of resources. At present, most of the teachers of construction engineering in colleges and universities go directly to colleges and universities to teach after their graduation. Although they have certain theoretical knowledge, new knowledge and organization methods are emerging with the advancement of building techniques and methods. Many teachers are separated from reality in teaching practice, for example, their speed of theoretical updating is slow and their knowledge structure is aging, which cannot be quickly adapted to the needs of teaching development. Some teachers lack necessary practical experience, and some teachers who have some experience in construction organization practice are still at the previous level. Under this circumstance, it is inevitable that teachers are separated from reality, and students guided by such teachers cannot meet the needs of society. Therefore, industry elites in the construction industry should be invited to participate in the seminar, to explore improvement measures for the current situation of talent training in colleges and universities, and to integrate the latest construction organization technology and actual needs of the enterprise into daily teaching.

\section{The FUnCTION AND STRUCTURE OF OPEN LEARNING}

Many of the problems mentioned above can be remedied through the reform and improvement of the traditional teaching model. In practice, the idea of construction organization teaching reform is mainly based on the full use of network resources. In the teaching, the concept that the need of students and employment is the teaching content should be thoroughly integrated into the teaching. The teaching reform idea of construction organization open learning model is "taking students as the main body, teachers as the leading and resources as the core" [3], through which teachers guide students to analyze and study independently, decompose teaching contents and cultivate students' practical application ability. Fig. 1 reflects the relationship between students and teachers in the open learning model.

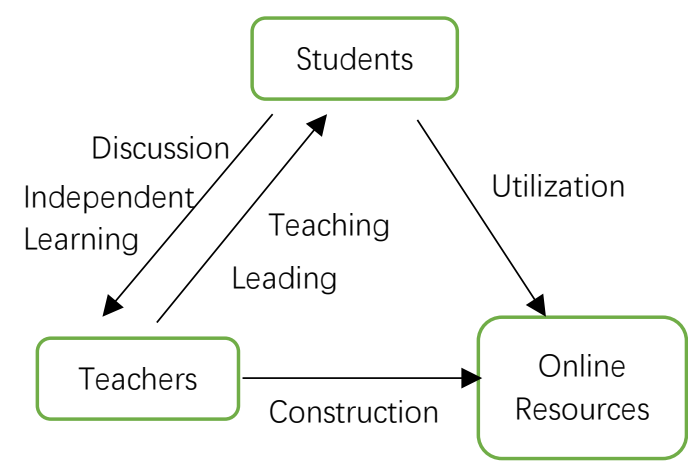

Fig.1. Open Learning Model Based on Online Courses

In the process of teaching and learning, students can rely on teachers, modern educational technology and network technology to make full use of online course teaching resources. Taking students' study and discussion as the center not only can cultivate students' ability to analyze and solving practical problems, but also can improve students' enthusiasm and initiative in learning, which will strengthen the interaction between teachers and students as well as improve teaching and learning. The establishment of an open learning environment gives students more autonomy and choice, which can fully tap the potential of students and enable students to produce whimsy in joint research. It not only changes the way students learn, but also respects the unique personality of students by changing teaching methods, which can promote the all-round development of students and create space for each student's development [4]. In addition, individual differences of students can be accommodated by categorizing and screening learning materials. The effect of open teaching model on teachers and students is summarized as shown in Fig. 2.

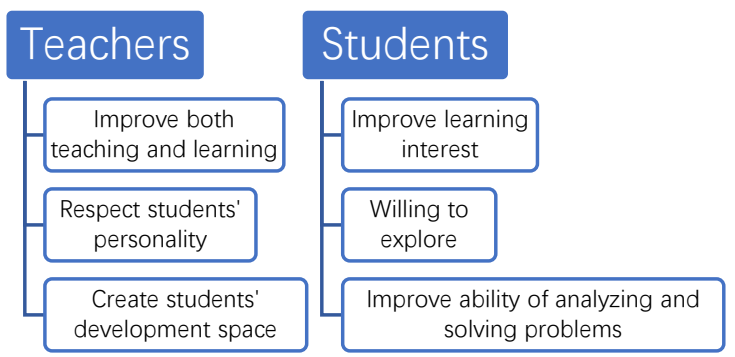

Fig.2. The Effect of Open Teaching Model on Teachers and Students

\section{IMPLEMENTATION STRATEGY}

\section{A. The objective of construction organization open learning} model

Through research, objectives of construction organization open learning model based on the construction organization curriculum reform are as follows:

1) To form an open learning model of construction organization

Establishing the open learning model of construction organization is mainly to solve the problem of insufficient learning initiative in the process of students' learning. Through 
active guidance, students can independently learn the resources provided by teachers through online open courses. In the specific operation, teaches mainly establish the resource library of the course, so that students can carry out not only the construction organization learning and data inquiry, but also network experiments and simulation training, so that students can fully enjoy the fun of independent learning. In the absence of opportunities for teaching and training, students can maximize the full use of teaching resources through independent learning.

2) To form an open evaluation model of construction organization

The establishment of the open evaluation model of construction organization mainly plays a role in supervising and inspecting students' learning. Students' abilities and endowments are different, and their motivation and consciousness of learning are different. By establishing such a model, the advantages of the network can be brought into play that is to realize real-time monitoring of students' learning process and learning results. Mastering the dynamics of students is conducive to adjusting teaching content so that it can meet the needs of students at different levels.

3) To form an open communication platform of construction organization

Establishing an open communication platform of construction organization can provide opportunities for teachers and students to communicate with each other. Through "online discussion", "email" or "questionnaire" in online open courses, teachers can communicate and interact with students in real-time. Teachers can have a deeper understanding of students' learning situation, so that teachers can provide students with the latest learning materials and learning resources, answer relevant questions raised by students, conduct corresponding information feedback, and constantly urge themselves to improve teaching methods.

\section{B. The operation of construction organization open learning model}

The operation of construction organization open learning model has two parts, one is students' model of operation, and the other is teachers' model of operation.

Students' model of operation: Open the online open course website of construction organization input the user name and password on the home page and enters the course interface. Courses generally set "course description", "teachers introduction", "syllabus", "teaching video", "teaching resources", "communication discussion" and "online training", which can be accessed by clicking directly. Students can arrange their own time, follow their teaching requirements and guidance, and learn independently about the issues they are interested in. They can also conduct online experiments and keep in touch and communicate with teachers through the communication system.

Teachers' model of operation: Teachers can make full use of multimedia technology in the classroom and make extensive use of network resources to assist teaching. After class, teachers can paste the courseware on the online open course webpage or send it to student's mailbox in order to facilitate students to consolidate the review. Teachers can also arrange question discussion for students, and then use the online discussion function to participate in the discussion or to comment on the opinions of students in the discussion, so that teachers can answer questions and clarify the right and wrong for students. This model solves the time limit of face-to-face communication between students and teachers to a certain extent, and also provides a broader space for students to learn independently.

\section{Construction guarantee of the open learning model}

The construction of an open learning model requires all aspects of guarantee. Firstly, it needs system guarantee, so it is necessary to establish a scientific and operational organization system. Organizational arrangements can help teaching work avoid arbitrariness and be more standardized and operable, since it has stronger standard ability and operability. Secondly, it needs technology guarantee. With the popularization and application of Internet technology, teachers and students use online open courses to assist with their teaching and learning more and more frequently. As the infrastructure of colleges and universities informatization, the online teaching platform has begun to take shape. Building a complete open teaching model requires support of professional technical strength. With the help of professionals, the teaching philosophy of teachers can be implemented. Finally, it needs teaching and funds guarantee, which requires a team of excellent teachers to make and implement the online course teaching plan to ensure the smooth implementation of the open teaching model. At the same time, teachers should continuously strengthen their self-learning, improve their knowledge structure and enhance their academic ability. Investment should be increased in funding, and all teachers should be encouraged to actively participate in the practice and exploration of the open learning model.

\section{RESEARCH ON AdVANTAges OF OPEN LEARNING MODEL}

\section{A. To realize the concept of equality and the need for personalization in education}

Traditional teaching activities are carried out through face-to-face communication between teachers and students, so there is a natural distance between teachers and students. Classroom teaching can only be carried out according to the situation of most students, which will inevitably make some students study very hard but some students learn easily. Under the open learning model, non-face-to-face communication between teachers and students shortens spatial distance and psychological distance, which facilitates effective communication under the attitude of maintaining equality [5]. At the same time, teachers can also provide guidance for different types of students through the network, and students can also feedback their requirements to teachers in a timely manner, so that teachers can grasp the situation and give individualized education.

\section{B. To give full play to students' initiative and enthusiasm}

In the classroom, students' thinking is often limited by the content taught by teachers. However, under the open learning model, students can fully share online teaching resources and 
maximize their initiative, enthusiasm and exploration spirit. They can collect relevant materials and cases of the course online, discuss issues on the communication platform, and download teaching software to coordinate with classroom learning. At the same time, it is also possible for students to complete more training subjects through network simulation training and improve practical operation capabilities. The open learning model plays an active role in improving learning interest and cultivating students' independent learning and creative thinking [6].

\section{To improve the comprehensive quality of teachers}

Traditional classroom teaching model has relatively low requirements for teachers, so their knowledge structure is at a low level or even an aging state. The open learning model puts forward higher requirements for teachers' ability and quality [7], which constantly requires teachers to conduct self-learning and self-improvement in professional knowledge, so that teachers can use information systems to continuously understand and learn the latest construction expertise and other knowledge. Teachers should not only manage the updating of online open courses but also communicate and connect with students through the course platform. They should also master relevant operational skills to meet the needs of teaching operations.

\section{To realize the maximum release of teaching resources}

At present, many colleges and universities have made large-scale investment in teaching infrastructure, therefore, resources and conditions for students' access to the Internet have been greatly improved, but at the same time, there lacks relevant means and guidance for resource utilization. Using the open learning model, teachers can publish ready-made teaching materials such as syllabus, teaching schedule, course handouts, key project cases, business process simulations and training materials on the Internet, and students can use a variety of methods to access the Internet, so that they can get more teaching resources and teaching guidance. In this way, existing teaching resources can be released and utilized.

\section{CONCLUSION}

Based on analyzing problems of traditional teaching in construction organization, this work researched on the expansion of teaching and learning, focusing on the learning model. It builds an open learning model of construction organization by using open online courses as carriers, which enables students to actively learn, exert their individuality and promote students' all-round development. At the same time, teachers can also improve their teaching ability in the open teaching model. The open learning model of construction organization teaching is in line with the teaching reform concept and quality education requirements, so it is an effective learning method.

\section{REFERENCES}

[1] Ahn, JY; Edwin, A. An e-Learning Model for Teaching Mathematics on an Open Source Learning Platform. [J]. International Review of Research in Open and Distributed Learning, vol. 19, 2018(05): 255 267.

[2] Ministry of Housing and Urban-Rural Development of the People's Republic of China. Code for Construction Organization Plan of Building Engineering (GB/T50502-2009) [S]. 2009.

[3] Li Yuanqing. Construction Organization Plan of Building Engineering and training[M]. Beijing: Peking University Press, 2014.

[4] Shi Zhenqiu. Cultivation of Post-ability of Vocational College Students Based on Open Learning Environment Theory[J]. Technology and Enterprise, 2013 (01): 239.

[5] Xu Feng. Research on the Structure of College Students' Learning Network Based on Social Network[D]. Jiangxi University of Finance and Economics, 2014.

[6] Tian Yuan. Research on the Enlightenment of Korean Open Learning Methods to the Study of Animation Students in China[D]. Northeast Normal University, 2016

[7] Yang Ming, Tian Nansheng. Enlightenment of Micro-courses on the Construction of Open Learning Environment[J]. Journal of Fuyang Vocational Technical College, 2015, 26 (01): 38-41. 